\title{
Implementasi Pendidikan Literasi Intrakurikuler Pada Mata Pelajaran Sosiologi di SMA Negeri 1 Linggo Sari Baganti Kabupaten Pesisir Selatan
}

\author{
Vera Yulinda ${ }^{1}$, Reno Fernandes ${ }^{2}$ \\ ${ }^{1,2}$ Universitas Negeri Padang \\ email: verayulinda917@yahoo.com, renofernandes@fis.unp.ac.id
}

\begin{abstract}
Abstrak
Artikel ini membahas implementasi pendidikan literasi intrakurikuler pada mata pelajaran sosiologi di SMA Negeri 1 Linggo Sari Baganti Kabupaten Pesisir selatan. Hasil penelitian ini dianalisis dengan menggunakan teori difusi inovasi yang dikemukakan oleh Rogers dan Kanuk. Penelitian ini dilakukan dengan pendekatan kualitatif tipe deskriptif. Dalam penelitian ini teknik pengumpulan data yang digunakan adalah observasi dan wawancara, pengumpulan dokumen yang berhubungan dengan topik penelitian dan studi kepustakaan. Setelah data terkumpul dikaji dengan teknik analisis data dari Miles dan Huberman. Hasil penelitian menunjukkan yang pertama, waktu dan tempat pelaksanaan kegiatan literasi dimulai di awal pembelajaran yang akan dimulai dan tempat pelaksanaannya di ruang kelas, yang kedua bentuk integrasi literasi dengan mata pelajaran adalah mengaitkan literasi dengan mata pelajaran tersebut, yang ketiga kurangnya sarana dan prasarana sekolah untuk menunjang Gerakan Literasi Sekolah (GLS) telah diterapkan di SMA Negeri 1 Linggo Sari Baganti, seharusnya pihak sekolah harus menyediakan seperti perpustakaan mini di kelas dan melengkapi gerakan literasi yang ada,namun dalam pelaksanaanya ada beberapa hal yang dirasa belum optimal seperti sarana dan prasarana sekolah yang belum mencukupi. Kata kunci : Intrakulikuler, Literasi, Sosiologi
\end{abstract}

\section{Abstract}

This article discuses how to implement intracuricular literacy education in sociology subjects at SMA Negeri 1 Linggo Sari Baganti, South Pesisir Regency. The results of this study were examined using the theory of innovation diffusion proposed by Rogers and Kanuk. This research was conducted with a qualitative type descriptive approach. In this study the data collection techniques used were observation and interviews, collecting documents related to research topics and literature studies. After the data has been collected it is examined with data analysis techniques from Miles and Huberman. The results showed the first, the time and place for literacy activities to begin at the beginning of learning to begin and the place for implementation in the classroom. The second form of literacy integration with subjects is to link literacy to these subjects. Thirdly, the lack of school facilities and infrastructure for Supporting the School Literacy Movement (GLS) has been implemented in SMA Negeri 1 Linggo Sari Baganti, the school should provide such a mini library in the classroom and complete the existing literacy movement, but in its implementation there are some things that are felt to be not optimal such as school facilities and infrastructure that not enough.

Keywords: Application, Education, Sociology Literacy

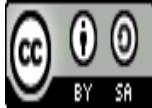

Received: October 15, 2019 Revised: December 4, 2019 Accepted: December 13, 2019




\section{Pendahuluan}

Buku seringkali masih menjadi satu-satunya sumber bacaan, sehingga hal ini tidak membuat generasi Indonesia menjadikan kegiatan membaca sebagai satu kebutuhan dalam hidup, terlebih lagi ketika dunia ini telah dikuasai teknologi informasi yang memungkinkan seseorang untuk mendapatkan ilmu pengetahuan dari berbagai media, sehingga kemudahan melihat informasi dari media audio-visual cenderung lebih disukai dan keinginan membaca menjadi rendah, meskipun hadirnya buku elektronik yang bisa diakses kapanpun, dimanapun, dan dalam situasi apapun. (Suragangga, 2017). Perkembangan informasi tidak selamanya berdampak positif, tetapi juga berdampak negatif. Salah satu dampak negatifnya yaitu rendahnya minat baca siswa di sekolah.

UNESCO mencatat pada tahun 2012 indeks minat baca di Indonesia baru mencapai 0,001 artinya dalam 1000 orang hanya ada satu orang yang berkegiatan membaca. Hasil penelitian Perpustakaan Nasional mengungkapkan bahwa masyarakat Indonesia rata-rata membaca sekitar 2-4 jam per hari, di bawah standar UNESCO sekitar 4-6 jam per hari. Masyarakat di negara maju rata-rata meluangkan 6-8 jam per hari untuk membaca. Di sisi lain, terdapat sekitar 30.000 judul buku yang diterbitkan setiap tahun oleh penerbit (Data Ikatan Penerbit Indonesia tahun 2016) Hasil survey yang dilakukan oleh Internasional Association for Evaluation of Educational menyebutkan bahwa kemampuan membaca siswa sekolah menengah atas kelas XI di Indonesia berada pada urutan ke -29 dari 30 negara, pada tahun 1996 menunjukkan urutan ke 41 dari 46 negara terteliti (Puspita \& Irwansyah, 2018).

Ketidaktertarikan pada kegiatan membaca, tidak hanya karena minat baca yang minim tapi juga karena ketersediaan buku yang bisa merangsang mereka untuk membaca memang kurang. Rendahnya minat baca akan berdampak buruk juga pada tingkat kualitas pendidikan. Kualitas pendidikan di Indonesia masih jauh tertinggal dari negara-negara tetangga. Rendahnya kualitas pendidikan berimplikasi pada kemampuan sumber daya dalam mengelola masa depan. Efek lain dari rendahnya kualitas pendidikan dapat dilihat pada Human Development Index (HDI) yang hanya berkisar di angka 0,728 atau berada pada urutan ke 107 dari 127 negara dan menempati posisi ke 7 untuk negara ASEAN.

Realita ini menunjukkan bahwa rendahnya minat baca siswa akan menimbulkan dampak buruk pada kualitas sumber daya manusia yang menuntut generasi cerdas, kreatif dan inovatif yang akan menjadi ujung tombak kemajuan bangsa. Pada tahun 2015 Kementrian Pendidikan dan Kebudayaan Indonesia Mengeluarkan Peraturan Menteri No 23 Tahun 2015 tentang penumbuh budi pekerti yang di dalamnya mencakup Gerakan Literasi Sekolah (GLS) merupakan sebuah upaya yang dilakukan secara menyeluruh untuk menjadikan sekolah sebagai organisasi pembelajaran yang mampu mengelola pengetahuan dan menjaga keberlanjutan pembelajaran dengan menghadirkan beragam buku bacaan dan mewadahi berbagai strategi membaca (Zuchdi dan Budiasih, 2017).

Prioritas pembangunan bidang pendidikan di Indonesia saat ini adalah peningkatan mutu pendidikan. Upaya inovasi pendidikan juga telah menjadi prioritas pemerintah, diantaranya adalah penyempurnaan kurikulum. (Sylvia, 2013). Telah termuat dalam kurikulum 2013 yang merupakan kurikulum nasional, yang salah satu program dalam kurikulum adalah pendidikan karakter. Dalam pendidikan karakter ini, yang perlu diperhatikan adalah timbulnya kebiasaan gemar membaca pada diri peserta didik. Untuk itu sekolah sebagai salah satu wadah penanaman pembiasaan membaca, melalui program Kementerian Pendidikan dan Kebudayaan mengembangkan Gerakan Literasi Sekolah yang pelaksanaanya melibatkan semua warga sekolah dan masyarakat, (Fernandes, 2017).

Idealnya gerakan literasi dimulai dengan memasukan kegiatan literasi ke dalam variasi model pembelajaran termuat dalam perencanaan perangkat pembelajaran, aktivitas belajar siswa, media dan evaluasi. Dalam perencanan pembelajaraan, guru merancang agar siswa dapat memahami materi tersebut melalui literasi yang dilakukan oleh siswa baik di lingkungan sekitarnya maupun melalui literasi media. Misalnya dalam kegiatan pendahuluan guru melakukan rencana kegiatan yaitu menugaskan kepada siswa untuk membaca materi dan mencari contoh yang berhubungan dengan materi yang dibelajarkan di media cetak ataupun 
online. Selanjutnya guru juga mengiringi aktivitas siswa tersebut dengan lembar kerja peserta didik. Pada kegiatan inti, guru mengimplementasikan pembelajaran yang telah dirancang dengan berbagai model pembelajaran, mengaitkan proses pembelajaran dengan kegiatan literasi dengan tujuan untuk meningkatkan motivasi pembelajaran dengan cara memulai kegiatan pembelajaran dengan membaca agar tercipta proses pembelajaran yang menarik (Indrahadi \& Junaidi, 2017). Pembelajaran merupakan suatu kegiatan interaksi yang dilakukan oleh peserta didik dengan lingkungannya. Dalam tahap evaluasi guru memberikan tugas berupa tes yang dilakukan untuk mengukur unjuk kerja siswa dengan tujuan agar siswa memahami pelajaran yang diterangkan oleh guru dengan menggunakan kegiatan gerakan literasi. (Elyusrah, n.d.).

Salah satu sekolah yang sudah mengembangkan gerakan literasi adalah SMAN 1 Linggo Sari Baganti Kabupaten Pesisir Selatan. Gerakan literasi sekolah di sekolah SMAN 1 Linggo Sari Baganti sudah diselenggarakan sejak akhir tahun 2016, kegiatan gerakan literasi yang dilakukan berdasarkan UU No 23 tahun 2015 dan surat keputusan dari kepala sekolah bahwa sekolah yang mempuyai akreditasi sekolah yang bagus wajib menerapkan kegiatan literasi tujuannya adalah untuk menumbuhkan minat baca terhadap siswa di sekolah. Kepala sekolah juga menunjuk beberapa orang guru di sekolah SMAN 1 Linggo Sari Baganti untuk menjadi panitia gerakan literasi demi kelancaran aktifitas gerakan literasi di SMAN 1 Linggo Sari Baganti. Tujuannya adalah agar dapat menumbuhkan kembali semangat membaca, tapi kenyaatan yang terlihat masih banyak siswa yang tidak mau membaca seperti perpustakaan masih sepi. Untuk itu pihak sekolah berupaya untuk menumbuhkan kembali minat baca (Francisco, 2013), salah satu kegiatan gerakan literasi yang direncanakan di SMAN 1 Linggo Sari Baganti adalah basic lieracy dan literacy media cetak. Sarana dan prasarana sekolah yang terbatas serta kurang memadai diterapkan berdampak pada keterbatasan proses belajar mengajar, sehingga pimpinan sekolah beserta guru mencoba menggiatkan gerakan literasi intrakurikuler.

Implementasi kegiatan literasi sekolah yang diintegrasikan ke dalam perencanaan dan proses pembelajaran di SMAN 1 Linggo Sari Baganti secara prosedur sudah berjalan tapi secara subtansi belum terlaksana dengan baik sesuai dengan tujuannnya. Seharusnya sejak ada pendidikan gerakan literasi disekolah SMA Negeri 1 Linggo Sari Baganti bisa meningkatkan minat belajar dan membaca pada diri siswa, tapi kenyataannya tidak ada pengaruh yang lebih maksimal terhadap siswa. Adapun yang menjadi tujuan penelitian ini adalah untuk mendeskripsikan implementasi pendidikan literasi intrakurikuler pada mata pelajaran sosiologi SMAN 1 Linggo Sari Baganti Kabupaten Pesisir Selatan. Manfaat dari penelitian ini terdiri atas dua yaitu manfaat teoritis dan manfaat praktis. Secara Teoritis (a) hasil penelitian ini diharapkan menjadi referensi guna penelitian ini lebih lanjut yang berkaitan dengan gerakan literasi di sekolah. (b) dapat menambah dan menguatkan teori-teori yang sudah ada khususnya tentang implementasi kegiatan literasi di sekolah dalam meningkatkan minat baca dan menulis siswa. Secara Praktis hasil penelitian ini diharapkan dapat bermanfaat bagi pihak-pihak berikut ini. (a) Bagi guru, sebagai masukkan untuk meningkatkan pembelajaran, khususnya pembelajaran literasi. (b) Bagi Siswa SMAN 1 Linggo Sari Baganti Kabupaten Pesisir Selatan dapat menambah motivasi siswa dalam pembelajaran literasi (c) Bagi peneliti lain, sebagai perbandingan untuk melakukan penelitian berikutnya. (d) Bagi peneliti sendiri, sebagai bahan untuk mendalami pembelajaran literasi.

Teori yang digunakan dalam penelitian ini adalah teori difusi inovasi yang dikemukakan oleh Rogers dan Kanuk asumsi dasar teori ini adalah inovasi dikomunikasikan melalui saluran tertentu dalam jangka waktu tertentu diantara para anggota suatu system sosial dan difusi dianggap sebagai suatu perubahan yang terjadi dalam struktur, fungsi dan sistem sosial. Dalam penelitian ini dapat dilihat bahwa kegiatan pendidikan literasi adalah salah satu terobosan baru dan perubahan baru yang signifikan yang sesuai dengan tuntunan zaman (Salim, 2014).

\section{Metode Penelitian}

Penelitian ini menggunakan pendekatan kualitatif dengan tipe deskriptif. Pendekatan kualitatif mencoba mengerti makna suatu kejadian atau peristiwa dengan mencoba berinteraksi dengan orang-orang dalam fenomena tersebut. (Suharsimi, 2005) menyatakan penelitian yang menggunakan pendekatan kualitatif adalah suatu proses penelitian ilmiah yang bermaksud untuk 
memahami masalah-masalah manusia dalam konteks sosial dengan menciptakan gambaran menyeluruh dan kompleks yang disajikan, melaporkan pandangan terperinci dari para sumber informasi, serta dilakukan dalam setting yang alamiah tanpa adanya intervensi apapun dari peneliti (Haris Herdiansyah, 2014). Sedangkan menurut Sukmadinata penelitian yang menggunakan pendekatan kualitatif yaitu suatu penelitian yang bertujuan untuk mendeskripsikan dan menganalisis fenomena, peristiwa, aktivitas sosial, sikap, kepercayaan, persepsi, pemikiran orang secara individu maupun kelompok (Sukmadinata, 2013). Dalam penelitian ini, peneliti mengambil tipe penelitian deskriptif karena tipe penelitian ini akan memberikan gambaran yang mendalam dan mendetail mengenai implementasi pendidikan literasi intrakurikuler pada mata pelajaran sosiologi SMAN 1 Linggo Sari Baganti Kabupaten Pesisir Selatan (Burhan Bungin, 2011).

Untuk mendapatkan informasi yang sesuai dengan pertanyaan yang diajukan, maka teknik pemilihan informan yang digunakan oleh peneliti adalah teknik purposive sampling yaitu penarikan sampel secara sengaja. Adapun kriteria informan dalam penelitian ini adalah : (1) Siswa-siswi yang SMAN 1 Linggo Sari baganti, (2) Guru sosiologi (3) Kepala Sekolah dan wakil kepala sekolah SMAN 1 Linggo Sari Baganti Kabupaten Pesisir Selatan. Teknik pengumpulan data yang digunakan dalam penelitian ini adalah teknik observasi, wawancara, studi dokumentasi, serta studi kepustakaan. Jenis analisis data yang digunakan dalam penelitian ini yaitu dengan mengadopsi yang dikembangkan oleh Milles dan Hurberman (Drs. S. Margono, 2010).

\section{Hasil dan Pembahasan}

\section{Hasil}

Gerakan literasi sekolah adalah salah satu terobosan baru yang dilaksanakan oleh pemerintah sejak tahun 2015, pemerintah berupaya untuk menugaskan kepada sekolah yang mempunyai akreditasi yang baik wajib menerapkan gerakan literasi tujuannya adalah untuk menumbuhkan kembali minat baca yang sudah perlahan-lahan hilang dalam diri siswa selain menumbuhkan minat baca dalam diri siswa pendidikan literasi juga bertujuan untuk maningkatkan motivasi pembelajaran dengan cara membaca (Lailatul Munawaroh, 2018).

Dalam konsep literasi, diartikan bahwa lirerasi adalah membaca menulis, berbicara serta berpikir kritis yang dijadikan sebagai usaha memahami, menggunakan, merefleksi, dan melibatkan diri dalam berbagai jenis teks untuk mencapai suatu tujuan. Dalam hal ini, membaca bertujuan mengembangkan pengetahuan dan potensi seseorang, serta untuk berpartisipasi dalam masyarakat. (Fernandes, Vidya Putra, \& Muspita, 2019)

Implementasi pendidikan literasi yang ada di sekolah SMAN 1 Linggo Sari Baganti berawal dari peraturan menteri UU No 23 tahun 2015 bahwa sekolah yang mempunyai akreditasi yang bagus wajib menerapkan literasi di sekolah, salah satu sekolah yang menerapkan gerakan literasi adalah SMAN 1 Linggo Sari Baganti adalah salah satu sekolah yang terbaik di Kecamatan Linggo Sari Baganti yang mana sekolah ini mendapatkan akreditasi A pada akhir tahun 2015, dan satu-satunya sekolah unggul di kecamatan Linggo Sari Baganti.

Sejarah pendidikan literasi di SMA N 1 Linggo Sari Baganti dimulai pada akhir tahun 2016, setelah dikeluarkan UU no 23 tahun 2015 dan penerapan kurikulum Kurikulum 2013, bahwa sekolah yang mempunyai akreditasi sekolah yang bagus wajib menerapkan pendidikan literasi tujuannya adalah untuk menumbuhkan minat baca terhadap siswa di sekolah, dan pada akhir tahun 2015 juga SMAN 1 Linggo Sari Baganti mendapatkan akreditasi A, dan dijadikan satu-satunya sekolah terfavorit di kecamatan Linggo Sari Baganti. Penyelenggaraan pendidikan literasi disekolah SMAN 1 Linggo Sari Baganti didasarkan pada surat keputusan dari kepala sekolah bahwa pendidikan literasi wajib dilaksanakan di SMAN 1 Linggo Sari Baganti dan beliau juga menugaskan kepada beberapa orang guru jadi panitia serta anggota dari gerakan literasi di sekolah tujuannya adalah untuk menumbuh kembangkan minat belajar dan membaca pada diri siswa. Pada kenyataannya pendidikan literasi yang ada di SMAN 1 Linggo Sari Baganti ini belum membawa dampak yang baik, secara prosedur sudah berjalan tapi secara 
subtansi belum berjalan semestinya. Seharusnya sejak ada pendidikan gerakan literasi sekolah bisa meningkatkan minat baca tapi kenyataan gerakan literasi hanya sebagai formalitas sekolah seperti dalam RPP yang dimiliki guru ada termuat gerakan literasi tapi dalam penerapan guru tidak ada melakukan gerakan literasi dan mengaitkan dengan mata pelajaran.

Penerapan literasi terhadap mata pelajaran sosiologi dimulai dari cara guru membuat perencanaan, pelaksanaan, dan evaluasi dalam perangkat pembelajaran. Dalam perencanaan pembelajaran ini seharusnya guru sudah mengintegrasikan model dan media pembelajaran yang bervariasi. Dalam pelaksanaan pembelajaran, kegiatan literasi di sekolah SMAN 1 Linggo Sari Baganti dimulai di awal pembelajaran saat pembelajaran berlangsung di kelas. Dalam kegiatan pendahuluan salah satu gerakan literasi yang dilakukan oleh guru di sekolah SMAN 1 Linggo Sari Baganti adalah basic literacy yaitu literasi dasar dan literasi media cetak dimana guru menugaskan kepada siswa untuk membaca 10-15 menit dan guru memberikan kepada siswa media cetak berupa bahan ajar agar memudahkan siswa dalam proses pembelajaran. Dalam kegiatan inti guru melaksanakan proses pembelajaran dengan mengimplementasikan kegiatan literasi yang telah direncanakan pada proses pembelajaran yang tujuannya adalah untuk meningkatkan motivasi siswa dengan cara guru melaksanakan proses pembelajaran menggunakan model pembelajaran yang bervariasi dengan menekankan proses pembelajaran pada aktivitas siswa sehingga mereka memulai kegiatan dengan membaca bahan cetak dan mengamati fenomena yang ada disekitarnya, agar tercipta proses pembelajaran yang menarik.

Dari segi waktu pelaksanaan, kegiatan literasi dimulai dari awal perencanaan pembelajaran yang dirancang oleh guru hingga akhir pembelajaran, dan dapat terjadi di dalam maupun di luar kelas, sehingga dapat diintegrasi dalam proses pembelajaran. Idealnya dengan penerapan gerakan literasi sekolah dalam bentuk gerakan literasi yang ada, dapat meningkatkan minat baca dan belajar siswa, namun dari penelitian lakukan tidak terlihat sama sekali aktivitas membaca siswa, bahkan perpustakaan masih sepi dan di sekolah ini juga tidak ada pojok baca seperti perpustakaan mini di kelas, dan media teknologi di sekolah SMA Negeri 1 Linggo Sari Baganti tidak ada.

Penerapan literasi yang ada di SMAN 1 Linggo Sari Baganti adalah kurangnya sarana dan prasarana sekolah sehingga pembelajaran literasi belum berjalan secara maksimal, seperti tidak ada perpustakaan mini di kelas, serta kurangnya proyektor yang dimiliki oleh sekolah sehingga pembelajaran dan media yang baik sangat sulit diterapkan guru, oleh karena itu guru pada akhirnya hanya membawakan metode ceramah dan diskusi, padahal siswa sangat menyukai pembelajaran dengan menggunakan media yang menarik seperti pada pembelajaran sosiologi seharusnya bisa nonton film, video serta gambar.

Untuk menunjang gerakan literasi sekolah (GLS) pihak sekolah pihak sekolah berupaya untuk menyediakan gerakan literasi sekolah yang ada seperti melengkapi perpustakaan mini dan menggunakan literasi media elektronik.

\section{Pembahasan}

Pendidikan yang berkualitas menjadi kebutuhan penting di era perkembangan teknologi dan informasi yang semakin pesat pada saat ini, buku tidak menjadi sumber utama dalam diri siswa melainkan media sosial yang mejadi hal paling utama untuk mencari berbagai sumber informasi (Lea Sakti Mitasari, 2017). Para pengambil kebijakan di tingkat pusat pastinya sudah menyadari akan hal tersebut. Untuk menjadikan dunia pendidikan berkualitas, tentu sangat banyak faktor yang berkaitan dan saling memengaruhi. Salah satu upaya pemerintah menjadikan pendidikan berkualitas adalah melalui meningkatkan budaya literasi (membaca dan menulis). Pemerintah melalui Permendikbud Nomor 23 Tahun 2015 telah menyadari pentingnya penumbuhan karakter peserta didik melalui kebijakan membaca.

Gerakan literasi sekolah adalah salah satu terobosan baru yang pemerintah adakan setelah adanya kurikulum 2013 dan penemuan baru dalam masyarakat, sebelumnya literasi belum ada diterapkan karena budaya membaca sudah perlahan-lahan mulai hilang maka pemerintah berupaya untuk menumbuhkan kembali minat baca yang dimiliki oleh siswa sebagai motivasi yang mampu menjadikan siswa memahami materi pembelajaran dengan cara membaca, 
(Wandasari, 2017). Sesuai dengan teori yang dikemukakan oleh Rogers (1995), asumsi dasar teori ini adalah proses dimana suatu inovasi seperti literasi itu adalah sesuatu yang baru atau penemuan baru yang diterapkan oleh pemerintah dan dikomunikasikan melalui para siswa dalam jangka waktu seperti disekolah di antara para siswa yang dianjurkan oleh pemerintah, disamping itu difusi juga dapat dianggap sebagai suatu jenis perubahan sosial yaitu suatu proses perubahan yang terjadi dalam struktur dan fungsi sistem sosial. Perubahan sosial disini yaitu perubahan kearah yang lebih baik terutama dalam membaca siswa sekarang dengan adanya teknologi budaya membaca sudah jarang digunakan oleh siswa karena dipengaruhi dengan perkembangan zaman, jadi kebijakan yang dilakukan pemerintah saat ini adalah membawa kearah yang lebih baik serta sesuai dengan fungsinya.

Dalam penerapan pendidikan literasi yang dilaksanakan di SMAN 1 Linggo Sri Baganti dari segi waktu pelakasaan literasi dimulai diawal pembelajaran yang akan dimulai dan tempat pelaksanaanya di ruang kelas, bentuk integrasi pendidikan literasi dalam mata pelajaran adalah mengaitkan literasi dengan mata pelajaran tersebut. Sarana dan prasarana pendukung kegiatan literasi yang ada disekolah SMAN 1 Linggo Sri Baganti adalah buku-buku yang digunakan adalah buku-buku mata pelajaran dan buku sumber lain seperti Novel, Majalah dan Koran.

\section{Kesimpulan}

Sesuai dengan hasil penelitian penulis lakukan di SMAN 1 Linggo Sri Baganti Kabupaten Pesisir Selatan terdapat beberapa hasil yang ditemukan diantaranya yaitu dari segi waktu pelaksanaan kegiatan literasi di sekolah SMAN 1 Linggo Sri Baganti dimulai diawal pembelajaran yang akan dimulai dan tempat pelaksaan kegiatan literasi adalah di ruang kelas yang melaksanakan kegiatan literasi adalah siswa dan siswi SMAN 1 Linggo Sri Baganti. Kemudian bentuk integrasi pendidikan literasi dalam mata pelajaran adalah mengaitkan literasi dengan materi pembelajararan. Serta sarana dan prasarana pendukung kegiatan literasi yang ada di sekolah SMAN 1 Linggo Sri Baganti adalah buku-buku mata pelajaran dan buku sumber lain seperti novel, majalah, dan koran.

\section{Daftar Pustaka}

Burhan Bungin. (2011). Metodelogi Penelitian. Jakarta: Rajawali Pers.

Drs. S. Margono. (2010). Metodelogi Penelitian Pendidikan. Jakarta: Rineka Cipta.

Elyusrah. (n.d.). Persiapan Pelaksanaan Program Gerakan Literasi Sekolah di Sekolah Menengah Atas Muhammadiyah 1 Boarding School di Desa Bentiring Kecamatan Bangkahulu, Bengkulu. Pengabdian Masyarakat Bumi Rafflesia, 90-103.

Fernandes, R. (2017). Adaptasi Sekolah terhadap Kebijakan Pendidikan Inklusif. Socius, 4,(2), $119-125$.

Fernandes, R., Vidya Putra, E., \& Muspita, R. (2019). Optimalisasi Institusi Pendidikan Sebagai Upaya Pengendalian Hoax. ABDI: Jurnal Pengabdian Dan Pemberdayaan Masyarakat, 1(1), 16-20. https://doi.org/10.24036/abdi/vol1-iss1/2

Francisco, A. R. L. (2013). Panduan Gerakan dan Gerakan Literasi Sekolah Menengah Atas. Journal of Chemical Information and Modeling, 53(9), 1689-1699. https://doi.org/10.1017/CBO9781107415324.004

Haris Herdiansyah. (2014). Metode Penelitian Kualitatif Untuk Ilmu-Ilmu Sosial. Jakarta: Salemba Humanika.

Indrahadi, D., \& Junaidi. (2017). Upaya meningkatkan kemampuan peserta didik berpikir kritis melalui penerapan srategi pembelajaran berbasis masalah pada pembelajaran sosiologi kelas xi ips 2 sma negeri 1 pariaman. 4(1), 22-30. https://doi.org/10.24036/scs.v4i1.14

Lailatul Munawaroh, S. A. (2018). Budaya Membaca Sebagai Implementasi Gerakan Sekolah di MI Ma'arif Gondosuli Muntilan. Jurnal Abdau, 1(2), 2622-3902.

Lea Sakti Mitasari. (2017). Peran Kegiatan Literasi Dalam Meningkatkan Minat Membaca dan Menulis Siswa Kelas Atas di SDN Gumpang. 1, 0. 
Puspita, G. A., \& Irwansyah, I. (2018). Pergeseran Budaya Baca dan Perkembangan Industri Penerbitan Buku di Indonesia: Studi Kasus Pembaca E-Book Melalui Aplikasi iPusnas. BIBLIOTIKA: Jurnal Kajian Perpustakaan Dan Informasi, 2(1), 13-20. https://doi.org/10.17977/um008v2i12018p013

Salim, A. (2014). Perubahan Sosial. Yogyakarta: tiara wacana.

Suharsimi. (2005). Manajemen Penelitian. Jakarta: Rineka Cipta.

Sukmadinata, N. S. (2013). Metode Penelitian Pendidikan. Bandung: Alfabeta.

Suragangga, I. M. N. (2017). Mendidik Lewat Literasi. Jurnal Penjaminan Mutu, 3(No.2). https://doi.org/10.25078/jpm.v3i2.195

Sylvia, I. (2013). Pemetaan Kompetensi Siswa SMA pada Mata Pelajaran Sosiologi di Kota Pariaman dan Kabupaten Padang Pariaman Provinsi Sumatera Barat. XIII no 1, 36.

Wandasari, Y. (2017). Implementasi Gerakan Literasi Sekolah (GLS) Sebagai Pembentuk Pendidikan Berkarakter. Manajemen, Kepemimpinan, Dan Supervisi Pendidikann, 1,(1), 325342 .

Zuchdi dan Budiasih. (2017). Implementasi Program Gerakan Literasi Sekolah Di Sd. Pendidikan Imlementasi Program Gerakan., 3, 732-744. 